\title{
Pengaruh Akuntabilitas, Transparansi dan Fungsi Pemeriksaan Intern Terhadap Kinerja Pemerintah Daerah (Studi Empiris Di Kabupaten Sorong)
}

\author{
FANNY JITMAU ${ }^{1}$, LINTJE KALANGI ${ }^{2}$, LINDA LAMBEY ${ }^{3}$ \\ PROGRAM MAGISTER AKUNTANSI, Fakultas Ekonomi Dan Bisnis Universitas Sam \\ Ratulangi
}

Email: jitmau.fanny@yahoo.com ${ }^{1}$

\begin{abstract}
In order to achieve a good performance of local governments, it requires accountability, transparency and internal audit functions. If those factors are implemented well, the performance of the local government will be excellent and satisfied. To achieve them, the existences of mechanisms for accountability and good performance management are required. Implementation of the existing rule and legislation relating to the application of the concepts of accountability and transparency in financial management is expected to create a good local government management and beneficial to people. Implementation of accountability and transparency in the financial management area is expected to improve the performance of local government. On the other hand, internal control must be conducted by government auditors in order to increase local government performance. This study aims to examine the influence of accountability, transparency and internal audit functions to regional government performance in Sorong. This is a quantitative research and data were collected by using questionnaires. Samples were taken from 100 respondents. They were from 10 SKPD in Sorong regency government. The data was analyzed by Multiple Linear Regression. Validity and reliability were examined by validity test, reliability test, classic assumption test, and hypothesis testing. The data were processed by using Statical Software Product and Services Solution (SPSS) 20.0 version. The results show that accountability does not influence the performance of local government in Sorong. However, transparency influences the local government performance and internal audit influences the performance of local government.
\end{abstract}

Keywords: Accountability, Transparency, Internal Audit Function and Performance of Regional Government.

Abstrak. Dalam pencapaian kinerja pemerintah daerah yang baik maka diperlukan akuntabilitas, transparansi serta fungsi pemeriksaan intern yang baik pula agar kinerja pemerintah daerah memiliki kualitas yang baik dan memuaskan. Dengan demikian, untuk memantapkan mekanisme akuntabilitas, diperlukan manajemen kinerja yang baik. Penerapan berbagai aturan perundang-undangan yang ada terkait dengan penerapan konsep akuntabilitas dan transparansi dalam pengelolaan keuangan diharapkan dapat mewujudkan pengelolaan pemerintah daerah yang baik dan berpihak kepada rakyat. Implementasi akuntabilitas dan transparansi dalam pengelolaan keuangan daerah ini diharapkan mampu meningkatkan kinerja pemerintah daerah. Disisi lain untuk meningkatkan kinerja pemerintah daerah perlu adanya fungsi aparat pemeriksa fungsional melaksanakan fungsi pemeriksaan intern yang merupakan suatu fungsi penilaian yang 
independen dalam suatu organisasi untuk menguji dan mengevaluasi kegiatan organisasi yang dilakukan. Penelitian ini bertujuan untuk menguji pengaruh akuntabilitas, transparansi dan fungsi pemeriksaan intern terhadap kinerja pemerintah daerah (Studi Empiris pada Pemerintah daerah Kabupaten Sorong). Jenis data yang digunakan pada penelitian ini adalah kuantitatif dan pengumpulan data digunakan kuesioner. Dalam penelitian ini diambil sampel dari 100 responden yang terdapat pada 10 SKPD di pemerintah Kabupaten Sorong. Metode analisis data yang digunakan yaitu regresi linier berganda, dengan pengujian validitas data, uji reabilitas data, uji asumsi klasik, dan uji hipotesis. Data diolah dengan menggunakan perangkat Software Statical Product And Services Solution (SPSS) versi 20. Hasil penelitian menunjukkan bahwa akuntabilitas tidak berpengaruh terhadap kinerja pemerintah daerah Kabupaten Sorong, transparansi berpengaruh terhadap kinerja pemerintah daerah Kabupaten Sorong, fungsi pemeriksaan intern berpengaruh terhadap kinerja pemerintah daerah.

Kata Kunci : Akuntabilitas, Transparansi, Fungsi Pemeriksaan Intern Dan Kinerja Pemerintah Daerah.

\section{Pendahuluan}

Pemerintah akan lebih menekankan aspek akuntabilitas pemerintahan dalam reformasi birokrasi pemerintahan. Untuk mewujudkan pertanggungjawaban pemerintah terhadap warganya salah satu cara dilakukan dengan menggunakan prinsip transparansi (keterbukaan). Melalui transparansi penyelenggaraan pemerintahan, masyarakat diberikan kesempatan untuk mengetahui kebijakan yang akan dan telah diambil oleh pemerintah. Juga melalui transparansi penyelenggaraan pemerintahan tersebut, masyarakat dapat memberikan feedback atau outcomes terhadap kebijakan yang telah diambil oleh pemerintah (Astuti, 2013).

Seperti halnya akuntabilitas, transparansi juga memiliki peran yang penting dalam penyelengaraan pemerintah karena dengan adanya transparansi maka masyarakat diberikan kesempatan untuk mengetahui kebijakan atau keputusan yang telah ditetapkan oleh pemerintah. Jadi, pemerintah memberikan informasi yang dibutuhkan oleh masyarakat tentang kebijakan yang diambil oleh pemerintah.

Disisi lain untuk meningkatkan kinerja pemerintah daerah perlu adanya fungsi pemeriksaan intern. Ratnawati dan Arnold (2011) menyatakan satuan kerja atau instansi yang berada dan dibentuk didalam dan merupakan bagian organisasi pemerintah, yang menjalankan tugas atau fungsi pemeriksaan terhadap organisasi pemerintah. Pemeriksaan intern pemerintah berfungsi utama membentuk pimpinan pemerintah melakukan tugas pemeriksaan dan pengendalian serta dapat memastikan keandalan sistem pengendalian intern pemerintah termasuk pengendalian akuntansi dan melaporkannya kepada pimpinan pemerintah di daerah. Lingkup pekerjaan pemeriksaan intern pemerintah tergantung pada penugasan dan kepentingan pimpinan pemerintah sehingga pengaruh pimpinan pemerintah sangat besar terhadap pemeriksaan intern. Pemeriksaan intern tidak melakukan pemeriksaan atas pertanggung jawaban keuangan Negara oleh pemerintah tetapi membantu pemerintah dalam menyusun pertanggungjawaban keuangan Negara. 
Jadi kinerja pemerintah perlu yang namanya fungsi pemeriksaan intern yang merupakan fungsi pemeriksaan intern yang dilakukan secara bebas atau tidak terikat agar kinerja pemerintah dapat dikatakan berkualitas dalam pertanggungjawaban, transparansi maka pemeriksaan intern juga tidak terdapat masalah tapi apabila ada terdapat masalah maka kinerja pemerintah daerah perlu dipertanyakan. Selain itu juga, fungsi pemeriksaan intern berperan untuk membantu pemerintah dalam menyusun pertanggungjawaban keuangan Negara.

Kinerja instansi pemerintah berkaitan erat dengan pengawasan, akuntabilitas dan transparansi. Memantapkan mekanisme akuntabilitas, diperlukan manajemen kinerja yang baik. Penerapan berbagai aturan perundang-undangan yang ada terkait dengan penerapan konsep akuntabilitas dan transparansi dalam pengelolaan keuangan diharapkan dapat mewujudkan pengelolaan pemerintah daerah yang baik dan berpihak kepada rakyat. Implementasi akuntabilitas dan transparansi dalam pengelolaan keuangan daerah ini diharapkan mampu meningkatkan kinerja pemerintah daerah (Wiguna, 2015).

Jadi jika akuntabilitas dan transparansi yang dilakukan pemerintah baik terhadap pengelolaan keuangan daerah maka dapat meningkatkan kinerja pemerintah jika tidak maka tidak dapat meningkatkan kinerja pemerintah karena hasil kinerja pemerintah akan diukur dari pencapaian akuntabilitas, transparansi dan fungsi pemeriksaan intern itu sendiri.

Oleh karena itu, dalam penelitian ini akan menganalisis tentang pengaruh akuntabilitas, transparansi dan fungsi pemeriksaan intern terhadap kinerja pemerintah daerah, di kabupaten Sorong. Meskipun sudah ada penelitian dengan topik sejenis, tetapi belum pernah dilakukan penelitian ini di daerah Kabupaten Sorong. Untuk itu dengan penelitian ini diharapkan dapat menambah kontribusi bagi dunia literatur. Dengan demikian, kiranya hasil studi ini dapat mendukung pembahasan dan teori yang sudah ada di dunia literatur.

Berdasarkan latar belakang, maka penelitian ini berjudul "Pengaruh Akuntabilitas, Transparansi Dan Fungsi Pemeriksaan Intern Terhadap Kinerja Pemerintah Daerah" (Studi Empiris di Kabupaten Sorong).

\section{Metode Penelitian}

Penelitian ini adalah survey dengan menggunakan pendekatan deskriptif kuantitatif. Survey adalah penelitian yang mengambil sampel dari satu populasi dan menggunakan kuesioner sebagai alat pengumpul data yang pokok (Singarimbun 1998, dikutip oleh Heristina, 2014). Survey merupakan studi yang bersifat kuantitatif yang digunakan untuk meneliti gejala suatu kelompok atau perilaku individu. Survey adalah suatu desain yang digunakan untuk penyelidikan informasi yang berhubungan dengan prevalensi, distribusi dan hubungan antar variabel dalam suatu populasi. Pada survey tidak ada intervensi, survey mengumpulkan informasi dari tindakan seseorang, pengetahuan, kemauan, pendapat, perilaku, dan nilai.

Dalam penelitian ini juga digunakan metode kausal yang dimaksudkan untuk menguji variabel-variabel independen yang diduga mempengaruhi variabel dependen. Model kausal biasanya menggunakan analisis regresi untuk menentukan mana variabel independen yang signifikan mempengaruhi variabel dependen (Kuncoro, 2011). 
Penelitian kuantitatif banyak digunakan terutama untuk mengembangkan teori dalam suatu disiplin ilmu. Penggunaan pengukuran disertai analisis secara statistik didalam penelitian mengimplikasikan bahwa penelitian ini menggunakan metode kuantitatif (Heristina, 2014). Jadi dalam penelitian ini peneliti akan menggunakan pendekatan kuantitatif dengan tujuan agar dapat mengembangkan teori dalam suatu disiplin ilmu dengan demikian pendekatan yang digunakan untuk menjawab permasalahan penelitian melalui teknik pengukuran yang cermat terhadap empat variabel yang akan diteliti. Kuncoro (2011) menyatakan kuantitatif adalah pendekatan ilmiah terhadap pengambilan keputusan manajerial dan ekonomi. Ibarat bahan baku dalam suatu pabrik, data ini diproses dan di sajikan menjadi informasi yang berharga bagi pengambilan keputusan.

\section{Populasi}

Sangadji dan Sopiah (2010) menyatakan populasi adalah wilayah generasi yang terdiri atas: subyek atau obyek dengan kualitas dan karakteristik tertentu yang ditetapkan oleh peneliti untuk dipelajari dan kemudian ditarik kesimpulan. Populasi memiliki dua status, yaitu sebagai berikut.

a) Sebagai obyek penelitian, jika populasi sebagai sumber informasi, tetapi sebagai subtansi yang di teliti, seperti kepuasan kerja, komitmen organisasional, kinerja karyawan (manajemen sumber daya manusia), perilaku konsumen, keputusan konsumen, pemasaran terpadu, strategi marketing (manajemen pemasaran), kebijakan deviden, profitabilitas, solvabilitas, rentabilitas, (manajemen keuangan), serta

b) Sebagai subyek penelitian, jika berfungsi sebagai sumber informasi. Misalnya, manusia, hewan, tumbuhan, dokumen, produk, dan lain-lain.

\section{Analisa Data dan Uji Asumsi Klasik}

Wibowo (2012) menyatakan bahwa uji asumsi digunakan untuk memberikan pre-test, atau uji awal terhadap suatu perangkat atau instrument yang digunakan dalam pengumpulan data, bentuk data, dan jenis data yang akan diproses lebih lanjut dari suatu kumpulan data awal yang telah diperoleh, sehingga syarat untuk mendapat data yang tidak bias menjadi terpenuhi atau, sehingga prinsip Best Linier Unbiased Estimator atau BLUE terpenuhi. Adapun uji asumsi klasik yang digunakan dalam penelitian ini meliputi uji multikorelasi, uji Normalitas dan uji heteroskedastisitas.

\section{Analisis Data}

Analisis data yang digunakan dalam penelitian ini adalah Regresi Linier Berganda yang akan dibantu dengan SPSS 20.0 maka dapat dilihat dalam rumus regresi berganda sebagai berikut (Azlim, 2012).

$Y=\alpha+\beta x_{1}+\beta x_{2}+\beta x_{3}+e$

\section{Hasil Penelitian dan Pembahasan}

Penyelenggaraan otonomi daerah merupakan bentuk kepercayaan yang diberikan oleh Pemerintah Pusat kepada daerah, yang secara langsung memberikan wewenang yang lebih luas kepada daerah untuk membangun daerahnya dan pelayanan yang lebih optimal kepada 
masyarakat. Untuk mencapai tujuan tersebut, dituntut adanya perubahan sistem nilai dan budaya kerja yang senantiasa dapat mengakomodasikan kebutuhan yang berorientasi kepada aspirasi masyarakat dengan prinsip-prinsip demokratisasi, pemerataan dan keadilan. Kondisi tersebut memerlukan kerangka pola pikir yang terstruktur untuk dapat memberdayakan fungsi publik, agar lebih sesuai dengan perkembangan ekonomi, politik, sosial dan budaya, sehingga diperlukan peningkatan budaya dan etos kerja yang berorientasi kepada pencapaian hasil serta pertanggungjawaban berdasarkan nilai-nilai akuntabilitas menuju good governance, yaitu Pemerintahan yang baik, bersih, berwibawa dan bertanggungjawab serta bebas dari korupsi, kolusi dan nepotisme. Laporan Akuntabilitas adalah media untuk mengeksplorasi dari mana sumber daya dan sampai sejauh mana prestasi Pemerintah Kabupaten Sorong diukur serta sampai sejauh mana upaya Pemerintah Kabupaten Sorong untuk dapat menyesuaikan dengan dinamika tuntutan perubahan masyarakat yang terus berkembang.

Penyusunan Laporan Akuntabilitas ini adalah keinginan yang kuat dari Pemerintah Kabupaten Sorong untuk mewujudkan tata kelola pemerintahan yang baik (good governance) dalam rangka mewujudkan tiga pilar tata pemerintahan yang baik yaitu Akuntabilitas, Partisipasi dan Transparansi.

\section{PENGARUH AKUNTABILITAS, TRANSPARANSI DAN FUNGSI PEMERIKSAAN INTERN TERHADAP KINERJA PEMERINTAH DAERAH (Studi Empiris Di Kabupaten Sorong)}

\section{Pengaruh Akuntabilitas Terhadap Kinerja Pemerintah Daerah}

Hasil pengujian hipotesis pada penelitian ini menjawab bahwa akuntabilitas tidak memiliki pengaruh terhadap kinerja pemerintah daerah dapat. Hal tersebut dapat dilihat pada nilai $-0,719$ lebih besar dari persamaan nilai signifikan yaitu 0,05. Maka nilai signifikansi dari akuntabilitas adalah $0,474>0.05$. Oleh karena itu, dapat disimpulkan bahwa akuntabilitas tidak berpengaruh secara signifikan terhadap kinerja pemerintah daerah. Berdasarkan hipotesis dalam penelitian ini maka hipotesis $\mathrm{H}_{01}$ diterima dan $\mathrm{H}_{\mathrm{a}}$ ditolak, dengan demikian penyebab akuntabilitas tidak berpengaruh terhadap kinerja pemerintah daerah adalah karena pemerintah gagal dalam menjalankan misi dalam mencapai tujuan dan sasaran yang telah ditetapkan sebelumnya secara periodik. Kinerja pemerintah dikatakan baik juga apabila setiap perencanaan pemerintah untuk mancapai hasil yang maksimal dari perencanaan tersebut salah satunya pertanggungjawaban pengelolaan keuangan daerah dilakukan dengan benar untuk mencapai tujuan yang ditetapkan, tetapi dalam penelitian ini sebaliknya pemerintah tidak melakukannya dengan benar. Perencanaan awal tidak sama dengan pencapaian hasil akhir karena ada saja yang gagal.

Dilihat juga penelitian terdahulu yang dilakukan oleh Astuti (2013) tentang Pengaruh akuntabilitas, transparansi dan fungsi pemeriksaan intern terhadap kinerja pemerintah daerah pada Dinas Pendapatan Pengelolaan Keuangan Dan Aset Daerah (DPPKAD) Kabupaten Grobogan yang menyatakan bahwa akuntabilitas tidak ada berpengaruh terhadap kinerja pemerintah daerah. Hasil pengujian hipotesis menunjukkan bahwa tidak ada pengaruh akuntabilitas terhadap kinerja pemerintah daerah di DPPKAD Kabupaten Grobogan dengan nilai sig sebesar 0,164, karena berada diatas nilai signifikansi yang dipersyaratkan yaitu 0.05 . Sehingga dapat disimpulkan bahwa akuntabilitas yang buruk dapat menurunkan kinerja pemerintah daerah. 
Sedangkan dalam penelitian ini berbeda juga dengan penelitian terdahulu oleh Wiguna (2015) pada Pemerintah Daerah Kabupaten Buleleng yang menujukkan bahwa akuntabilitas pengelolaan keuangan berpengaruh signifikan terhadap kinerja Pemerintah Daerah Kabupaten Buleleng. Koefisien regresi dari variabel Akuntabilitas Pengelolaan Keuangan Daerah sebesar 0,187 dan bertanda positif yang berarti bahwa apabila terjadi peningkatan Akuntabilitas Pengelolaan Keuangan Daerah sebesar satu, maka akan menyebabkan meningkatnya Kinerja Pemerintah Daerah sebesar 0,187 dengan nilai koefisien determinasi sebesar $21,0 \%$ Selanjutnya mengacu pada hasil tabel diatas, diketahui bahwa nilai t- hitung $>$ t- tabel $(2,212>1,694)$ dengan nilai probability $(\alpha=$ $5 \%)=0,035$ dibawah 0,05 . Hal ini berarti $\mathrm{Ha}$ dapat diterima dan Ho ditolak sehingga "Akuntabilitas pengelolaan Keuangan Daerah berpengaruh signifikan terhadap kinerja Pemerintah Daerah Kabupaten Buleleng".

Jika dilihat dari definisi akuntabilitas pada sub pembahasan sebelumnya akuntabilitas dapat diartikan sebagai bentuk kewajiban mempertanggung jawabkan keberhasilan atau kegagalan pelaksanaan misi organisasi dalam mencapai tujuan dan sasaran yang telah ditetapkan sebelumnya, melalui media pertanggungjawaban secara periodik (Gala, 2013). Pengertian akuntabilitas (Mardiasmo, 2009) yang menyatakan akuntabilitas publik yaitu kewajiban pihak pemegang amanah (agent) untuk memberikan pertanggungjawaban, menyajikan, melaporkan, dan mengungkapkan segala aktivitas dan kegiatan yang menjadi tanggungjawabnya kepada pihak pemberi amanah (principal) yang memiliki hak dan kewenangan untuk untuk meminta pertanggungjawaban tersebut. Akuntabilitas terdiri atas dua macam yaitu (1) akuntabilitas vertikal (vertical accountability), dan (2) akuntabilitas horizontal (horizontal accountability). Pertanggungjawaban vertikal (vertical accountability) adalah pertanggungjawaban atas pengelolaan dana kepada otoritas yang lebih tinggi, misalnya pertanggungjawaban unit-unit kerja (dinas) kepada pemerintah daerah, pertanggungjawaban pemerintah daerah kepada pemerintah pusat, dan pemerintah pusat kepada MPR. Pertanggungjawaban horizontal (horizontal accountability) adalah pertanggungjawaban kepada masyarakat luas.

\section{Pengaruh Transparansi Terhadap Kinerja Pemerintah Daerah}

Hasil pengujian hipotesis pada penelitian ini menjawab bahwa transparansi memiliki terhadap kinerja pemerintah daerah dapat dilihat pada nilai 4,199 lebih besar dari persamaan nilai signifikan yaitu 0,05. Maka nilai signifikansi dari transparansi adalah $0,000<$ 0,05 . Oleh karena itu, dapat disimpulkan bahwa transparansi berpengaruh secara signifikan terhadap kinerja pemerintah daerah. Berdasarkan hipotesis dalam penelitian ini maka hipotesis $\mathrm{H}_{\mathrm{a} 2}$ diterima dan $\mathrm{H}_{02}$ ditolak, penyebab transparansi berpengaruh terhadap kinerja pemerintah daerah adalah karena transparansi melalui SKPD mengungkapkan informasi keuangan dan non-keuangan kepada publik melalui media secara tepat waktu, memadai, jelas, akurat dan dapat diperbandingkan serta mudah diakses oleh pihak-pihak berkepentingan (stakeholders) sesuai dengan haknya. Melalui transparansi juga tersedianya informasi yang memadai tentang penyusunan rencana kerja dan informasi laporan keuangan daerah diberikan tepat waktu dan handal kalau transparansi atau ketebukaan pemerintah dalam memberikan informasi tentang aktivitas pengelolaan sumber daya publik kepada pihak-pihak yang membutuhkan informasi tersebut. 
Penelitian ini sama dengan penelitian sebelumnya juga dengan penelitian terdahulu oleh Wiguna (2015) pada Pemerintah Daerah Kabupaten Buleleng yang menunjukkan bahwa transparansi pengelolaan keuangan berpengaruh signifikan terhadap kinerja Pemerintah Daerah Kabupaten Buleleng. Koefisien regresi dari variabel Transparansi Pengelolaan Keuangan Daerah sebesar 0,683 dan bertanda positif yang berarti bahwa apabila terjadi peningkatan Transparansi Pengelolaan Keuangan Daerah sebesar satu, maka akan menyebabkan meningkatnya Kinerja Pemerintah Daerah sebesar 0,683 dengan nilai koefisien determinasi sebesar 38,9\%. diketahui bahwa nilai t-hitung > t-tabel $(3,263>$ $1,694)$ dengan nilai probability $(\alpha=5 \%)=0,003$ dibawah 0,05 . Hal ini berarti Ha dapat diterima dan Ho ditolak sehingga "Transparansi pengelolaan Keuangan Daerah berpengaruh signifikan terhadap kinerja Pemerintah Daerah Kabupaten Buleleng".

Penelitian ini berbeda dengan penelitiannya Astuti (2013) yang menunjukkan bahwa transparansi tidak berpengaruh terhadap kinerja organisasi pada DPPKAD Grobogan dengan nilai signifikansi 0,266 , yang berarti tidak signifikan karena berada diatas nilai signifikansi yang dipersyaratkan yaitu 0,05. Dengan demikian dapat disimpulkan bahwa transparansi yang kurang baik dapat menurunkan kinerja pemerintah daerah pada satuan kerja perangkat daerah khususnya di DPPKAD Kabupaten Grobogan.

Jika dilihat dari definisi transparansi pada sub pembahasan sebelumnya transparansi adalah adanya kebijakan terbuka bagi pengawasan. Sedangkan yang dimaksud dengan informasi adalah informasi mengenai setiap aspek kebijakan pemerintah yang dapat dijangkau publik. Keterbukaan informasi diharapkan akan menghasilkan persaingan politik yang sehat, toleran, dan kebijakan dibuat beradasarkan preferensi publik. Makna dari transparansi dalam penyelenggaraan pemerintahan daerah dapat dilihat dalam dua hal yaitu (1) salah satu wujud pertanggungjawaban pemerintah kepada rakyat, dan (2) upaya peningkatan manajemen pengelolaan dan penyelenggaraan pemerintahan yang baik dan mengurangi kesempatan praktek kolusi, korupsi dan nepotisme (KKN).

Rohmah (2011) menyatakan transparansi meliputi keterbukaan dalam memberikan informasi yang nantinya dapat menghasilkan persaingan politik yang sehat, bertoleransi dan kebijakannya dibuat berdasarkan atas preferensi masyarakat. Sehingga dapat disimpulkan bahwa transparansi adalah keterbukaan dalam memberikan informasi, pengetahuan dan gambaran mengenai keuangan partai politik kepada publik yang nantinya informasi tersebut menjadi penilaian kinerja masyarakat terhadap partai politik dalam mewujudkan kepentingan dan aspirasi rakyatnya.

\section{Pengaruh Fungsi Pemeriksaan Intern Terhadap Kinerja Pemerintah Daerah}

Hasil pengujian hipotesis pada penelitian ini menjawab bahwa fungsi pemeriksaan intern memiliki pengaruh terhadap kinerja pemerintah daerah dapat dilihat pada nilai 1,933 lebih besar dari persamaan nilai signifikan yaitu 0,05. Sedangkan nilai signifikansi dari fungsi pemeriksaan intern adalah 0,056 besar dari 0.05 maka dikatakan tidak signifikan tetapi apabila digunakan sig 0,10 maka fungsi pemeriksaan intern berpengaruh signifikan terhadap kinerja pemerintah daerah. Berdasarkan hipotesis dalam penelitian ini maka dapat dikatakan $\mathrm{H}_{\mathrm{a} 1}$ diterima dan $\mathrm{H}_{01}$ ditolak dengan demikian maka penyebab fungsi pemeriksaan intern berpengaruh terhadap kinerja pemerintah daerah adalah fungsi pemeriksaan intern 
berbicara tentang hasil yang dicapai dalam setiap kegiatan SKPD. SKPD memiliki Pedoman, Sistem, dan Prosedur Kerja seluruh tingkatan atau jenjang organisasi SKPD yang tersedia secara lengkap, kini, dan sesuai dengan ketentuan dan perundang-undangan yang berlaku, SKPD telah bertindak sebagai pemerintahan yang baik termasuk peduli terhadap lingkungan dan melaksanakan tanggungjawab sosial (Corporate Social Responsibility/CSR). SKPD mengidentifikasikan masalah analisa dan evaluasi dilakukan secara independen dan konstruktif dengan pemberian pendapat apabila diperlukan. Pemeriksaan secara umum dapat diartikan sebagai suatu proses yang sistematis untuk mengidentifikasikan masalah analisa dan evaluasi yang dilakukan secara independen dan konstruksif serta dengan pemberian pendapat atau apabila di pandang perlu direkomendasi. Pemeriksaan atas keuangan negara dapat dilakukan oleh pemeriksaan intern dan pemeriksa eksteren pemerintah. Berdasarkan Undang-Undang yang ditetapkan, dan pelaksanaan pemeriksaan berpedoman pada suatu standar pemeriksaan. Dalam pelaksanaan pengawasan dapat dilakukan atau dilengkapi dengan pemeriksaan akan tetapi tidak setiap kegiatan pengawasaan harus dilakukan melalui pemeriksaan, seperti pengawasan yang dilakukan antara lain oleh DPR dan masyarakat. Satuan kerja atau instansi yang berada dan dibentuk didalam dan merupakan bagian organisasi pemerintah. Pemeriksaan intern pemerintah berfungsi utama membentuk pimpinan pemerintah, melakukan tugas pemeriksaan dan pengendalian serta dapat memastikan keandalan sistem pengendalian intern pemerintah termasuk pengendalian akuntansi dan melaporkannya kepada pimpinan pemerintah pusat di daerah (Ratnawati dan Arnold, 2011).

Hasil penelitian ini sama dengan penelitian sebelumnya juga dengan penelitian terdahulu oleh Ratnawati dan Arnold (2011) menjelaskan bahwa fungsi pemeriksaan intern memiliki pengaruh positif signifikan terhadap kinerja pemerintah daerah. Fungsi pemeriksaan internal yang baik akan menghasilkan kinerja institusi yang lebih tinggi. Selanjutnya penelitian yang sama dilakukan oleh Rohman (2007), tentang Pengaruh Peran Manajerial Pengelola Keuangan Daerah dan Fungsi Pemeriksaan Intern Terhadap Kinerja Pemerintah Daerah (Survey Pada Pemda, Kota, Kabupaten, Dan Provinsi Dijawa Tengah) dan hasil penelitian ini menunjukkan bahwa peran manajerial PKD, dan fungsi pemeriksaan intern berpengaruh terhadap kinerja pemerintah.

\section{Kesimpulan}

Berdasarkan hasil penelitian dan pembahasan tentang Pengaruh Akuntabilitas Transparansi Dan Fungsi Pemeriksaan Intern Terhadap Kinerja Pemerintah Daerah kabupaten Sorong. Dapat diambil kesimpulan sebagai berikut.

1. Akuntabilitas tidak berpengaruh secara signifikan terhadap Kinerja Pemerintah Daerah Kabupaten Sorong dengan nilai signifikan -0,474 lebih besar dari persamaan sig 0,05 maka dapat disimpulkan bahwa akuntabilitas tidak berpengaruh terhadap kinerja pemerintah daerah kabupaten Sorong.

2. Transparansi berpengaruh Terhadap Kinerja Pemerintah Kabupaten Sorong dapat dilihat pada nilai sig 0,000 lebih kecil dari persamaan sig yang ditentukan 0,05 maka dapat disimpulkan bahwa Transparansi berpengaruh terhadap Kinerja Pemerintah Daerah Kabupaten Sorong. 
3. Fungsi pemeriksaan intern berpengaruh Terhadap Kinerja Pemerintah Kabupaten Sorong dapat dilihat pada nilai 0,056 yang lebih besar dari nilai persamaan yang ditentukan 0,05 tetapi jika digunakan nilai sig 0,10 maka dapat disimpulkan bahwa Fungsi Pemeriksaan Intern berpengaruh terhadap Kinerja Pemerintah Kabupaten Sorong.

\section{Saran}

Berdasarkan hasil penelitian diatas maka saran yang dapat diberikan adalah sebagai berikut.

1. Untuk pemerintah kabupaten Sorong lebih meningkatkan kualitas akuntabilitas, agar hasil kinerja pemerintah kabupaten Sorong dapat dilihat nyata dalam segi pertanggungjawaban pemerintah yang berkualitas dengan demikian akan memiliki dampak yang baik bagi masyarakat kabupaten Sorong. IFAC (2001) dikutip oleh Ibrahim (2015) menyatakan akuntabilitas adalah proses dimana entitas sektor publik, dan individu-individu didalamnya, bertanggungjawab atas keputusan dan tindakan mereka, termasuk pengelolaan dana publik mereka dan semua aspek kinerja. Akuntabilitas adalah kewajiban untuk menjawab tanggungjawab yang diberikan.

2. Kepada pemerintah kabupaten Sorong agar lebih ditingkatkan lagi kinerja pemerintah melalui transparansi yang baik bagi penggunaan informasi atau masyarakat agar pengelolaan keuangan daerah tetap handal dan akurat. Riswanto (2016) menyatakan kinerja instansi pemerintah berkaitan erat dengan akuntabilitas dan transparansi. Penerapan berbagai aturan perundang-undangan yang ada terkait dengan penerapan konsep akuntabilitas dan transparansi dalam pengelolaan keuangan diharapkan dapat mewujudkan pengelolaan pemerintah daerah yang baik dan berpihak kepada rakyat. Implementasi akuntabilitas dan transparansi dalam pengelolaan keuangan daerah ini diharapkan mampu meningkatkan kinerja pemerintah daerah.

3. Kepala SKPD lebih ditingkatkan kualitas kinerja pemerintah melalui fungsi pemeriksaan intern yang baik agar kualitas pengelolaan keuangan tetap berjalan berdasarkan perencanaan yang ditentukan oleh peraturan perundang-undangan daerah. Ratnawati dan Arnold (2011) menyatakan pemeriksaan intern berfungsi utama membentuk pimpinan pemerintah melakukan tugas pemeriksaan dan pengendalian, serta dapat memastikan keandalan sistem pengendalian intern pemerintah termasuk pengendalian akuntansi dan melaporkannya kepada pimpinan pemerintah pusat di daerah.

\section{Daftar Pustaka}

Astuti, M, Ratih. 2013. Pengaruh Akuntabilitas, Transparansi dan Fungsi Pemeriksaan Intern Terhadap Kinerja Pemerintah Daerah (Studi Kasus Pada Dinas Pendapatan Pengelolaan Keuangan Dan Aset Daerah (DPPKAD) Kabupaten Grobogan). Naskah Publikasi. Fakultas Ekonomi Dan Bisnis Universitas Muhammadiyah Surakarta 2013.

Azlim, 2012. Pengaruh Penerapan Good Governance Dan Standar Akuntansi Pemerintahan Terhadap Kualitas Informasi Keuangan SKPD Di Kota Banda Aceh.

Gala. A. Merlin. 2013. Pengaruh Penerapan Sistem Akuntansi Keuangan Daerah Terhadap Akuntabilitas Publik Pada Pemerintah Kabupaten Gorontalo. 
Heristina, ananda. Kita Bisa (Internet). Jenis-Jenis Penelitian, 28 November 2014, (dikutib 16 Maret 2016). Tersedia dari : http:anandaheristina.blogspot.co.id/2014/11/jenis-jenis penelitian.html.

Ibrahim, Pradanadi, S, D. 2015. Pengaruh anggaran berbasis kinerja, transparansi, Akuntabilitas, dan Pengawasan Internal Terhadap Kinerja Pegawai Sekretariat Jenderal DPR RI. Fakultas Ekonomi dan Bisnis Universitas Bina Nusantara Email: pradanadi_saksesadi@gmail.com.

Kuncoro, Mudrajad. 2011. Metode Kuantitatif, Teori dan Aplikasi Untuk Bisnis \& Ekonomi (edisi keempat).

Mardiasmo. 2009. Akuntansi Sektor Publik.

Natak, Riswanto. 2016. Analisis Pengaruh Akuntabilitas Dan Transparansi Pengelolaan Keuangan Daerah Terhadap Kinerja Pemerintah Daerah Kabupaten Jember. Jurusan Akuntansi, Fakultas Ekonomi, Universitas Jember (UNEJ) JIn. Kalimantan 37, Jember 68121 E-mail: natakriswanto25@gmail.com.

Ratnawati, J. Arnold, C, W. (2011) Peran Manajerial Pengelola Keuangan Daerah, Dan Fungsi Pemeriksaan Intern Serta Pengaruhnya Terhadap Kinerja Pemerintah Daerah.

Rohmah, Lailatur. 2011. Persepsi Mahasiswa Akuntansi Unesa Tentang Pengaruh Transparansi Dan Akuntabilitas Keuangan Partai Politik Terhadap Kinerja Partai Dan Upaya Pemberantasan Kejahatan Kerah Putih. Universitas Negeri Surabaya Lailaturrohmah10@gmail.com.

Roman, Abdul. 2007. Pengaruh Peran Menejerial Pengelola Keuangan Daerah dan Fungsi Pemeriksa Intern Terhadap Kinerja Pemerintah Daerah (Survei pada Pemda Kota, Kabupaten dan Provinsi di Jawa Tengah). Fakultas Ekonomi Universitas di Ponegoro.

Sangadji, Etta Mamang, Sopiah. 2010. Metodologi Penelitian Pendekatan Praktis dalam Penelitian.

Wibowo, E, Agung. 2012. Aplikasi praktis SPSS dalam penelitian.

Wiguna, S, Budi. 2015. Pengaruh Pengawasan Keuangan Daerah, Akuntabilitas Dan Transparansi Pengelolaan Keuangan Daerah Terhadap Kinerja Pemerintah Daerah Kabupaten Buleleng. Jurusan Akuntansi Program S1 Universitas Pendidikan Ganesha Singaraja, Indonesia. 